\title{
ASSESSMENT OF OIL PALM PLANTATION AND TROPICAL PEAT SWAMP FOREST WATER QUALITY BY MULTIVARIATE STATISTICAL ANALYSIS
}

\author{
${ }^{1}$ Seca Gandaseca, ${ }^{2}$ Noraini Rosli, \\ ${ }^{2}$ Mohammad Shawkat Hossain and ${ }^{1}$ Chandra Imam Arianto \\ ${ }^{1}$ Department of Forest Production, Faculty of Forestry, Universiti Putra Malaysia, \\ 43400 UPM Serdang, Selangor, Malaysia \\ ${ }^{2}$ Faculty of Agriculture and Food Sciences, Universiti Putra Malaysia Bintulu Sarawak Campus, \\ Nyabau Road, Post Box No. 396, 97008 Bintulu, Sarawak, Malaysia
}

Received 2012-11-30; Revised 2014-06-30; Accepted 2014-07-04

\begin{abstract}
This study reports the spatio-temporal changes in river and canal water quality of peat swamp forest and oil palm plantation sites of Sarawak, Malaysia. To investigate temporal changes, 192 water samples were collected at four stations of BatangIgan, an oil palm plantation site of Sarawak, during July-November in 2009 and April-July in 2010. Nine water quality parameters including Electrical Conductivity (EC), pH, Turbidity (TER), Dissolved Oxygen (DO), Temperature (TEMP), Chemical Oxygen Demand (COD), fiveday Biochemical Oxygen Demand $\left(\mathrm{BOD}_{5}\right)$, ammonia-Nitrogen $\left(\mathrm{NH}_{3}-\mathrm{N}\right)$, Total Suspended Solids (TSS) were analysed. To investigate spatial changes, 432 water samples were collected from six different sites including BatangIgan during June-August 2010. Six water quality parameters including pH, DO, COD, $\mathrm{BOD}_{5}, \mathrm{NH}_{3}-\mathrm{N}$ and TSS were analysed to see the spatial variations. Most significant parameters which contributed in spatio-temporal variations were assessed by statistical techniques such as Hierarchical Agglomerative Cluster Analysis (HACA), Factor Analysis/Principal Components Analysis (FA/PCA) and Discriminant Function Analysis (DFA). HACA identified three different classes of sites: Relatively Unimpaired, Impaired and Less Impaired Regions on the basis of similarity among different physicochemical characteristics and pollutant level between the sampling sites. DFA produced the best results for identification of main variables for temporal analysis and separated parameters (EC, TER, COD) and identified three parameters for spatial analysis $\left(\mathrm{pH}, \mathrm{NH}_{3}-\mathrm{N}\right.$ and $\left.\mathrm{BOD}_{5}\right)$. The results signify that parameters identified by statistical analyses were responsible for water quality change and suggest the possibility the agricultural and oil palm plantation activities as a source of pollutants. The results suggest dire need for proper watershed management measures to restore the water quality of this tributary for a healthy and promising terrestrial and aquatic ecosystem.
\end{abstract}

Keywords: Water Quality, Multivariate Analysis, Oil Palm Plantation, Peat Swamp Forest, Malaysia

\section{INTRODUCTION}

The surface water quality is affected by both the anthropogenic activities and natural processes (Carpenter et al., 1998; Mokaya et al., 2004; Melina et al., 2005; Singh et al., 2005). Natural processes influencing water quality include precipitation rate, weathering processes and sediment transport. The anthropogenic activities may include exploitation of forest resources by human activities, conversion of pristine peat swamp forest into oil palm plantation by the traders, deforestation for mitigating wood demand, urban

Corresponding Author: Seca Gandaseca, Department of Forest Production, Faculty of Forestry, Universiti Putra Malaysia, 43400 UPM Serdang, Selangor, Malaysia 
development and expansion, industrial and agricultural practices. These activities often results in the degradation of water quality, physical habitat and biological integrity of lotic system (Yayýntas et al., 2007). The effects of timber harvesting on stream water quality and efficiency of alternate streamside management zones has been studied in Pockwock Lake of Nova Scotia, Canada (Vaidya et al., 2008). In Sarawak, Malaysia, the tropical peat swamp forest is under threat of aforementioned anthropogenic activities which may in turn lead to deterioration of river water quality, loss of biodiversity and ecosystem dysfunctions.

The assessment of environmental quality is mostly based on vast amounts of physical, chemical and biological data, which if processed using descriptive univariate methods is of little value to decision makers. Simple assessments can be made using descriptive statistics and some graphical representations. However, the problem of derivation of information on possible influences of the environment on water quality with these simple approaches becomes more and more complicated as the number of parameters is increased. Accordingly, multivariate techniques are needed to achieve satisfactory results. These techniques offer greater possibilities to managers in terms of aiding the decision-making process and have been proven as suitable for environmental quality assessment (Sanchez Lopez et al., 2004).

Various multivariate statistical methods, such as Cluster Analysis (CA) and Discriminant Function Analysis (DFA), help in the interpretation of complex data sets, such as those created by long-term water quality monitoring programs, allowing a better understanding of the temporal and spatial variations in water quality and in the identification of discriminant parameters that are of use in optimizing monitoring network (Shrestha and Kazama, 2007; Simeonov et al., 2003). In the last decade, multivariate statistical methods have been applied to characterize and evaluate freshwater (Astel et al., 2006; Kowalkowski et al., 2006; Papatheodorou et al., 2006; Shin and Fong, 1999; Shrestha and Kazama, 2007; Simeonov et al., 2002; 2003; Simeonova et al., 2003; Singh et al., 2004; Vega et al., 1998; Wunderlin et al., 2001), groundwater (Adams et al., 2001; Helena et al., 2000; Lambrakis et al., 2004; Singh et al., 2005; Suk and Lee, 1999) and seawater (Reghunath et al., 2002; Yeung, 1999; Yung et al., 2001). According to previous researches, multivariate statistical methods were proved as one of useful tools to extract the meaningful information from data set, for example, (Simeonov et al., 2003; Astel et al., 2006) applied CA to delineate the monitoring sites, (Singh et al., 2005; Shrestha and Kazama, 2007) used CA and DFA to identify the significant parameters and optimize the monitoring network. However, CA and DFA were not comprehensively applied in the analysis of surface water quality in oil palm and peat swamp forests of Sarawak, Malaysia. The main objectives of the present study was to classify the monitoring sites into groups with similar levels of water quality parameters and to use multivariate statistical techniques to assess the spatial and temporal variations in water quality in order to establish baseline study of water quality. Water quality parameters were subjected to Hierarchical Agglomerative Cluster Analysis (HACA), Factor Analysis/Principal Components Analysis (FA/PCA) and Discriminant Function Analysis (DFA) to extract latent information about the similarities or dissimilarities among the monitoring periods or sites, to identify water quality variables responsible for temporal and spatial variations in water quality and to test of the validity of the results in temporal and spatial DFA.

\section{MATERIALS AND METHODS}

\subsection{Monitoring Area and Sampling}

Two sets of experiments had been conducted to investigate temporal and spatial variations of surface water quality.

\subsubsection{Experiment 1 (EXP-1)}

The study has been conducted in BatangIgan, Sibu, Sarawak (central coordinates: $2^{\circ} 15^{\prime} \mathrm{N}$ and $111^{\circ} 58^{\prime} \mathrm{E}$ ). The BatangIgan is anoil palm plantation site of Sarawak, Malaysia. This site experiences tropical climate with high humid air and annual rainfall is more than $4000 \mathrm{~mm}$ (SMD, 2014). The wet season (September to December), intermediate season (January to April) and dry season (May to August) contribute 46,31 and $23 \%$ of the annual rainfall, respectively. The site is crisscrossed by different river networks. The quality of the river water is influenced by the BatangIganoil palm plantation activities.

To study temporal variations of water quality, surface water samples were collected from four stations. Station 1 was located in a small river which runs along the main road; also the entry point of palm oil plantation. This river water discharges water to the palm oil plantation through irrigated canals connected to this river. Thus palm oil plantation activity has influence on this river water quality. Station 2 is located inside this palm oil plantation. The depth of river at these stations varies 
from 2-3 $\mathrm{m}$. The station 3 and station 3 and 4 are located in a canal which is an artificial irrigation canal built inside the palm oil plantation area. Depth of those canals is about $1 \mathrm{~m}$. Sampling stations and rivers are shown in Fig. 1.

\subsubsection{Experiment 2 (EXP-2)}

To investigate the spatial variation of surface water quality, another set of experiments were being conducted at six sites, namely, Batang Igan Sibu Sarawak (BISS), Sepadok Bintulu Sarawak (SBS), Pandan Sebauh Bintulu Sarawak (PSBS), Ladang Semanok Tatau Sarawak (LSTS), Sungai Parit Scheme (SPS) and Sungai Sibuti (SS). The PSBS and SBS are natural peat swamp forest areas, whereas, the BISS and LSTS is converted into oil palm plantation site which were covered with peat swamp forest until 2008.

The SPS and SS are located at Sibuti Wildlife Sanctuary Mangrove Forest, Miri, Sarawak (central coordinates: $3^{\circ} 58^{\prime} 60^{\prime \prime} \mathrm{N}$ and $\left.113^{\circ} 43^{\prime} 60^{\prime \prime} \mathrm{E}\right)$. The SS is a natural river while the SPS is an artificial drainage built by Sarawak Forestry Corporation (SFC) in the mangrove area. The mangrove reserve is dominated by Rhizophora species.

\subsection{Monitored Parameters and Analytical Methods}

\subsubsection{EXP-1 (Temporal Variations of Water Quality)}

To study temporal variations of water quality, 192 surface water samples in 8 replicates were collected from four stations during July, August and November in 2009 and April, June and July in 2010 (Table 1). Nine water quality parameters were monitored during above mentioned six months. The parameters included Electrical Conductivity (EC), pH, Turbidity (TER), Dissolved Oxygen (DO), Temperature (TEMP), Chemical Oxygen Demand (COD), five-day Biochemical Oxygen Demand $\left(\mathrm{BOD}_{5}\right)$, AmmoniaNitrogen $\left(\mathrm{NH}_{3}-\mathrm{N}\right)$, Total Suspended Solids (TSS).

\subsubsection{EXP-2 (Spatial Variations of Water Quality)}

To study spatial variations, 432 water samples were collected from 4 stations of the six study sites (Table 1). Water samples were collected about $10 \mathrm{~cm}$ below water using plastic bottles $(500 \mathrm{~mL})$ and BOD bottles. The water samples for physico-chemical analysis were kept in ice for further analysis in the laboratory. In situ data measurement was recorded using Water Quality Meter (Model WQC-24). The sampling, preservation, transportation and analysis of the water samples were performed according to standard methods (APHA, 2005).
Six water quality parameters monitored during JuneAugust 2010. The parameters included pH, DO, COD, $\mathrm{BOD}_{5}, \mathrm{NH}_{3}-\mathrm{N}$ and TSS (Table 1). All the water quality parameters are expressed in $\mathrm{mg} \mathrm{L}^{-1}$, except $\mathrm{pH}$, EC $\left(\mu \mathrm{S} \cdot \mathrm{cm}^{-1}\right)$, Turbidity (NTU) and TEMP $\left({ }^{\circ} \mathrm{C}\right)$.

\subsection{Statistical Analysis}

The multivariate statistical techniques have been widely used in various studies for the explanation of patio-temporal variations and interpretation of chemical/physical characteristics of water quality parameters (Simeonov et al., 2000; Wunderlin et al., 2001; Singh et al., 2005) in comparison to univariant techniques that usually fail to give adequate information on multivariate dataset (Santos-Roman et al., 2003). In the present study three multivariate techniques such as HACA, PCA/FA and DFA were used for the water quality assessment and interpretation of the results.

\subsubsection{HACA Analysis}

HACA was used for grouping of data set on the basis of spatial similarities (Kent and Coker, 1992; Angeler et al., 2007; Sánchez-Carrillo et al., 2007). It is an unsupervised pattern recognition method that divides a large group of cases into smaller groups or clusters of relatively similar cases that are dissimilar to other groups. Hierarchical CA, the most common approach, starts with each case in a separate cluster and joins the clusters together step by step until only one cluster remains (Lattin et al., 2003; McKenna, 2003). The Euclidean distance usually gives the similarity between two samples and a distance can be represented by the difference between transformed values of the samples (Otto, 1998). In this study, HACA was performed on the mean values of all water quality parameters studied at different sampling stations over the whole period. The Ward's method with squared Euclidean distances was used as a measure of similarity. Ward's method uses Analysis of Variance (ANOVA) to calculate the distances between clusters to minimize the sum of squares of any two possible clusters at each step. Euclidean distances were chosen as a measure of similarity that uses analysis of variance to evaluate the distances between clusters, attempting to minimize the sum squares ofany two clusters that can be formed at each step (Kent and Coker, 1992). Spatial and temporal variations in water quality were determined from HACA using the linkage distance. A similar approach has been successfully applied to the assessment of water quality in (Wunderlin et al., 2001; Simeonov et al., 2003; Singh et al., 2004; 2005; Shrestha and Kazama, 2007; Kowalkowski et al., 2006; Astel et al., 2006). 


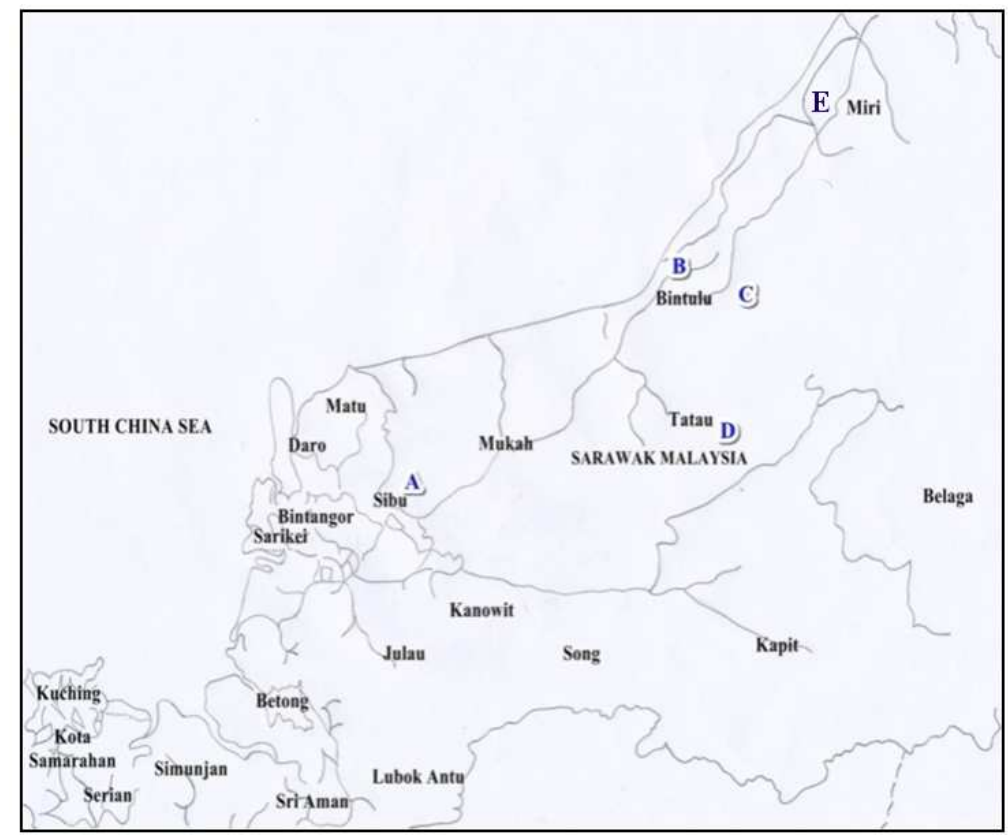

Fig. 1. Water sampling locations, $A=B I S S, B=S B S, C=P S B S, D=L S T S, E=S P S$ and SS

Table 1. Summary of water sample collection site, duration and parameters under EXP-1 and 2

\begin{tabular}{|c|c|c|c|c|c|}
\hline$\overline{\text { EXP }}$ & Observed variations & Study Site & Nos. of replicates & Sample collection time & Water quality parameter \\
\hline 1 & Temporal & BISS & $\begin{array}{l}192(4 \text { stations } \times 8 \\
\text { replicates } \times 6 \text { months })\end{array}$ & $\begin{array}{l}\text { Wet (Nov. 2009), } \\
\text { intermediate (Apr. 2010) } \\
\text { and dry seasons (Jul.-Aug. } \\
2009 \text { and May-Jun. 2010) }\end{array}$ & $\begin{array}{l}\mathrm{pH}, \mathrm{EC}, \mathrm{TER}, \mathrm{DO}, \mathrm{TEMP}, \\
\mathrm{COD}, \mathrm{BOD}_{5}, \mathrm{NH} 3-\mathrm{N} \text { and TSS }\end{array}$ \\
\hline 2 & Spatial & $\begin{array}{l}\text { BISS, SBS, } \\
\text { PSBS, LSTS, } \\
\text { SPS and SS }\end{array}$ & $\begin{array}{l}432(4 \text { stations } \times 6 \\
\text { replicates } \times 6 \\
\text { sites } \times 3 \text { months })\end{array}$ & Jun.-Aug. 2010 & $\begin{array}{l}\mathrm{pH}, \mathrm{DO}, \mathrm{COD}, \mathrm{BOD}_{5}, \\
\mathrm{NH}_{3}-\mathrm{N} \text { and TSS }\end{array}$ \\
\hline
\end{tabular}

\subsubsection{DFA Analysis}

A second technique DFA was used to determine the water quality parameters that best discriminate between groups identified by HACA. It's a method of analyzing dependence that is a special case of canonical correlation and one of its objectives is to determine the significance of different variables, which can allow the separation of two or more naturally occurring groups. DFA operates onoriginal data and the method constructs a discriminant function for each group (Johnson and Wichern, 1992; Lattin et al., 2003; Wunderlin et al., 2001) as follows:

$$
f\left(G_{i}\right)=k_{i}+\sum_{j=1}^{n} w i_{j} \cdot p i j
$$

where, $i$ is the number of Groups $(G), k_{i}$ is the constant inherent to each group, $\mathrm{n}$ is the number of parameters used to classify a set of data into a given group, $w_{j}$ is the weight coefficient, assigned by DFA to a given parameter $\left(p_{j}\right)$. In this study, DFA was performed on original data using the standard, forward stepwise and backward stepwise modes to evaluate the temporal variation in water quality. The best discriminant functions for each mode were constructed considering the quality of the classification matrix and the number of parameters. The monitoring periods were the grouping variables and the measured parameters were the independent variables.

\subsubsection{PCA/FA Analysis}

Third technique used was PCA based on DFA to identify the important physio-chemical parameters which affect the water quality/chemistry of surface water and to investigate the possible sources of different pollutants. 
PCA/FA was performed of on three regions of sites separately classified by HACAas RUR, IR and LIR. This method has been used by (Singh et al., 2005; Hill and Lewicki, 2006) to extract lower dimensional linear structure from the water quality data set and has been applied for source identification (Voutsa et al., 2001). PCA is powerful pattern recognition technique that attempts to explain the variance of a large set of intercorrelated variables with a smaller set of independent variables (principal components). The PCA technique starts with the covariance matrix describing the dispersion of the original variables and extracting the eigen values and eigenvectors. An eigenvector is a list of coefficient by which original correlated variables is multiplied to obtain new uncorrelated or orthogonal variables (principal components) which are weighted linear combinations of the original variables. A Principal Component (PC) is the product of original data and an eigenvector is the result of the data projected on to anew axis. There are as many PCs as original variables, but provides information about the most meaningful parameters (Vega et al., 1998; Wunderlin et al., 2001). The initial set of components generated by PCA is not readily interpreted; therefore it is usually transformed by Varimax rotation. FA reduces the contribution of less significant variables obtained from PCA and the new groups of variables known as Varimax Factors (VFs) are produced by rotating the axis defined by PCA.

\section{RESULTS}

\subsection{Temporal Variations of Water Quality}

To investigate seasonal variations of water quality, descriptive statistics (mean, median, standard deviation) of each data set is given in Table 2.

Median values which are not affected by extreme values were taken into consideration as characteristics values to see the differences in the two different seasons (Table 2). Comparing the median values, it can be concluded that EC, TER, NH3-N and TSS were highest and BOD and $\mathrm{pH}$ were lowest in the intermediate among the three seasons. On the other hand, the median concentration of DO and BOD were clearly higher in the dry season compared to intermediate and wet seasons. The $\mathrm{pH}$ and COD median concentration were highest in the wet season compared to other two seasons and showed a clear-cut temporal effect.
Most multivariate statistical methods require variables to conform to the normal distribution. Thus, Shapiro-Wilk test was used to examine whether or not variables are normally distributed and also to investigate homogeneity of covariance matrices. Results revealed that generally the data set does not represent a sample from a multivariate normal distribution and variance/covariance matrices of variables are not homogeneous across groups $(p<0.05$; Table 3). Therefore, logarithmic transformation was used to stabilize the variance of data sets and to render the data dimensionless (Liu et al., 2003; Singh et al., 2004) before DFA was applied.

In order to understand the distribution modes of different water parameters in water samples and discriminate the different seasons, PCA was carried out. The first two factor loadings (accounting for a cumulative variance of $\sim 93 \%$ ) are shown in Table 4 , giving the two main groups of variables: (1) TSS, COND, TEMP, TURB and BOD (characterised by very negative factor 1 values) and (2) $\mathrm{COD}, \mathrm{pH}$ and DO (characterised by very negative factor 2 values).

The grouping images (dendro grams) from the analysis Fig. 2 show variables (sampling stations) ordered in similar clusters, while the distances between the points on the horizontal axis represent the order of affinity or proximity. The dendro gram shows seasonal variations with different characteristics with respect to the measured water quality parameters in four different stations of BISS.

After segregating raw data into three seasonal groups (dry, wet and intermediate), DFA was applied for the evaluation of temporal variations. The goal of the DFA was to find one or two functions of the observed data (called discriminant functions) that best separate the two known groups (seasons). Stepwise DFA was applied to water parameter variables and results revealed that EC, TUR and COD were statistically significant to discriminate seasons. The first two functions (linear combinations) that provide the largest separation among dry, intermediate and wet seasons are the first and second Discriminant Functions (DF) as given below Equation 1 and 2, respectively:

$$
\begin{aligned}
& D F 1=0.642 E C-0.811 T U R+1.295 C O D \\
& D F 2=1.082 E C-0.281 T U R-0.032 C O D
\end{aligned}
$$


Each of the samples obtained in wet, intermediate and dry seasons were transformed to discriminant scores using these two discriminant functions separately for all water parameter variables (Fig. 3). Inspecting Fig. 3, the data from the three seasons appear to have been well separated by the discriminant functions. Predicted values of discriminant functions were also revealed that $95.5 \%$ of original group cases for water parameter variables were correctly classified. Thus, water quality variables (naturally found in surface water and also pollutants) were distinctly different for the three seasons.

\subsection{Classification of Sampling Sites Based on Water Quality Parameters}

HACA performed on the water quality data set to evaluate spatial variation among sampling sites resulted in grouping of sampling stations into three groups (Fig. 4). The sites within each group showed similar water quality parameters. These groups were coded based upon impairment by different pollutants as Relatively Unimpaired Region (RUR), Impaired Region (IR) and Less Impaired Region (LIR). Sites SS and SPS were placed in RUR group that represent area under Sibuti Wildlife Sanctuary Mangrove Forest. Sites at BISS and LSTS were included in IR group representing the oil palm plantation sites which were converted from the peat swamp forest. Sites PSBS and SBS were grouped in LIR cluster and were present natural peat swamp forest areas.

For spatial variations among different sites, DFA was applied on raw data after grouping into three main groups defined by HACA. Groups (RUR, IR and LIR) were treated as dependent variables, while water quality parameters were treated as independent variables. The results revealed that $\mathrm{pH}, \mathrm{NH}_{3}-\mathrm{N}$ and $\mathrm{BOD}$ were statistically significant to discriminate spatial variations.

The first two functions (linear combinations) that provide the largest separation among RUR, IR and LIR are the first and second DF Equation 3 and 4 respectively:

$$
\begin{aligned}
& D F 1=8.171 p H+15.108 \mathrm{NH}_{3}-N+13.290 B O D \\
& D F 2=0.618 p H+0.655 \mathrm{NH}_{3}-N+0.263 B O D
\end{aligned}
$$

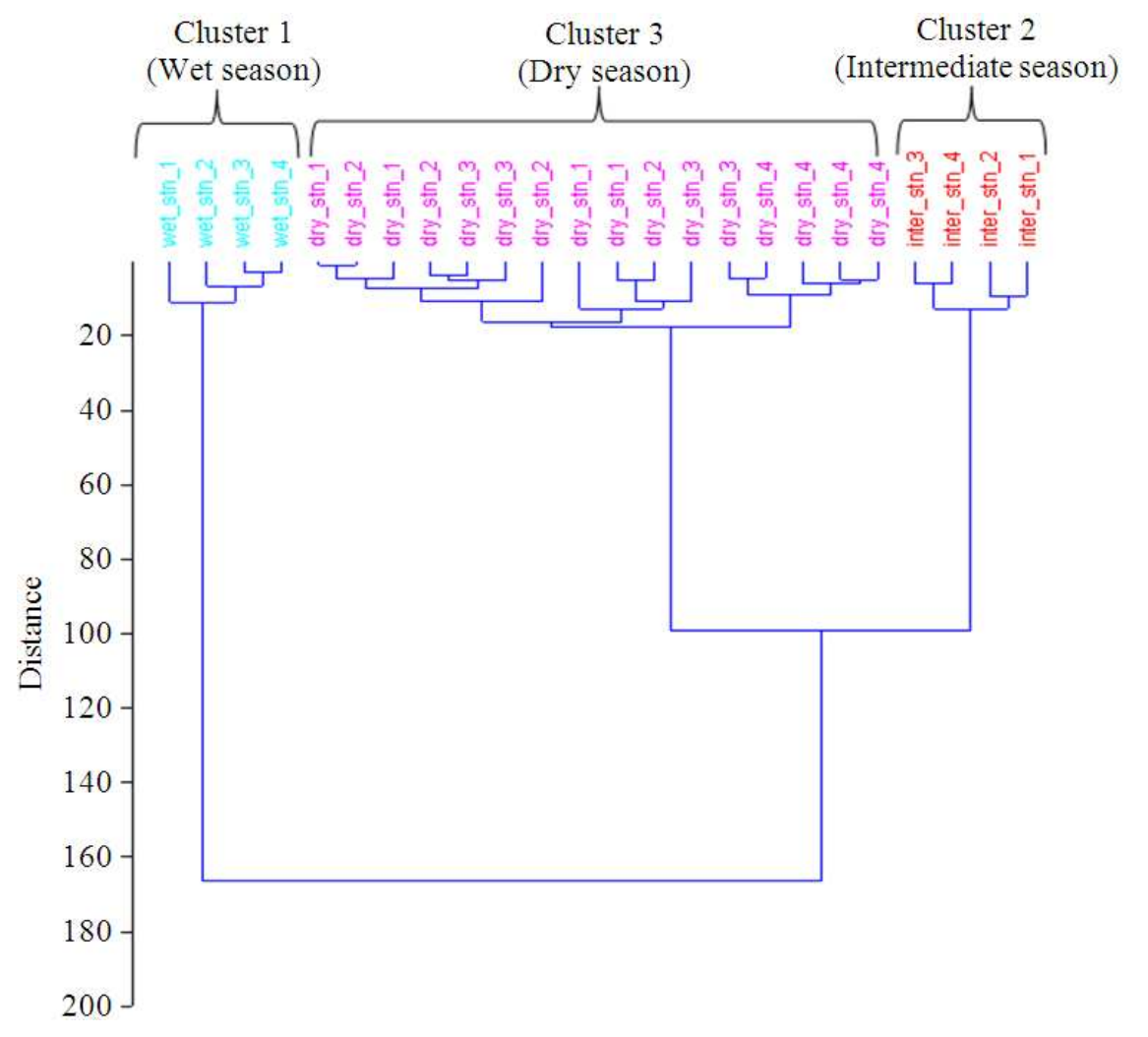

Fig. 2. Cluster analysis of three different seasons based on the water quality parameters collected 
Seca Gandaseca et al. / American Journal of Environmental Sciences 10 (4): 391-402, 2014

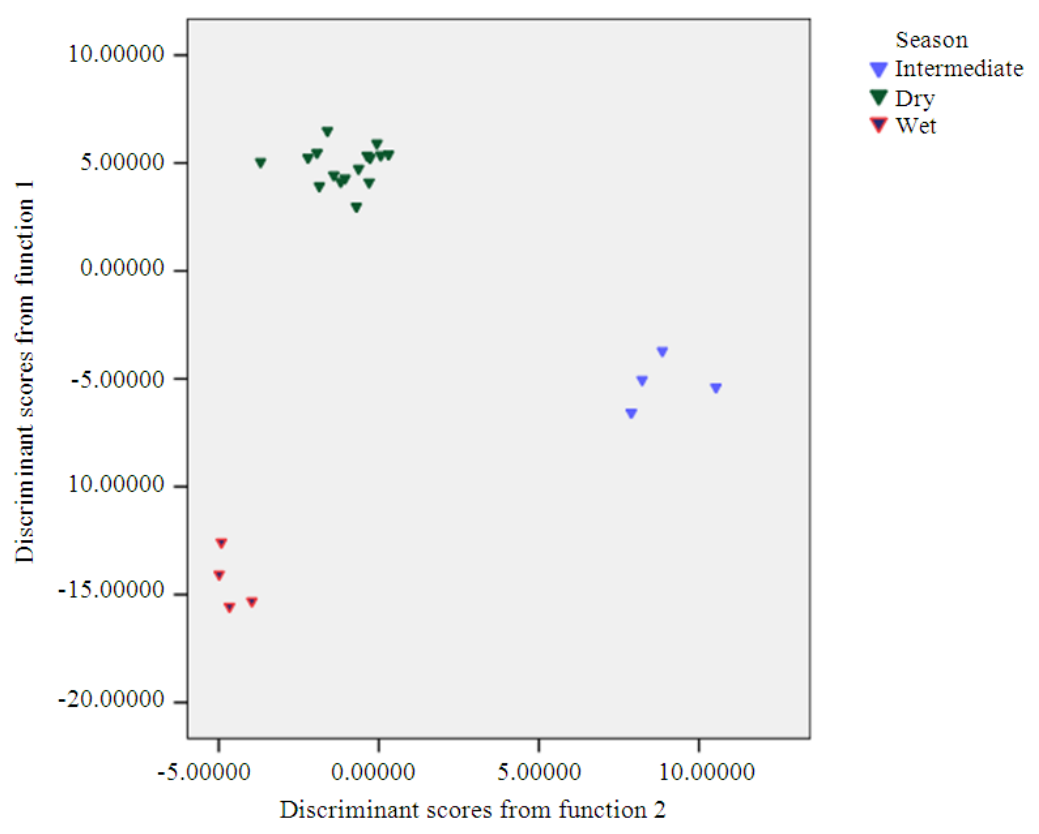

Fig. 3. Discriminant scores for water parameter variables

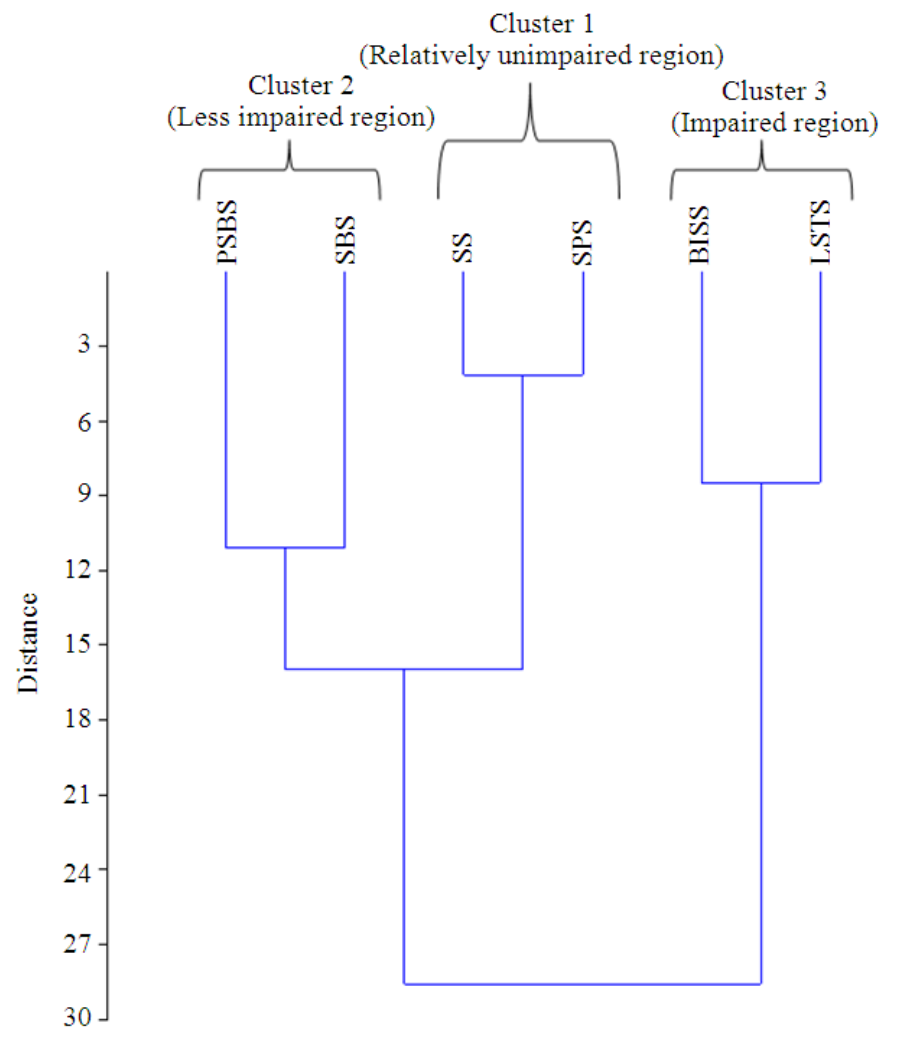

Fig. 4. Dendrogram showing different clusters of sampling sites based on the water quality. parameters collected under EXP-2 
Table 3. Shapiro-wilk test results

\begin{tabular}{lc}
\hline Water parameters & P value \\
\hline pH & 0.139 \\
TEMP & 0.026 \\
EC & 0.000 \\
DO & 0.036 \\
TER & 0.260 \\
$\mathrm{NH}_{3}-\mathrm{N}$ & 0.002 \\
BOD & 0.002 \\
COD & 0.000 \\
TSS & 0.000 \\
\hline
\end{tabular}

Table 4. Loadings and water parameters on the first two otated Principal Components (PC) for water samples

\begin{tabular}{lcr}
\hline & Component & \\
Water parameter & - PC 1 & PC 2 \\
\hline pH & 0.108 & 0.607 \\
TEMP & 0.512 & 0.347 \\
EC & 0.944 & -0.136 \\
DO & -0.129 & -0.799 \\
TER & 0.725 & 0.433 \\
$\mathrm{NH}_{3}-\mathrm{N}$ & 0.716 & -0.479 \\
BOD & 0.923 & 0.165 \\
COD & 0.101 & 0.993 \\
TSS & 0.986 & -0.084 \\
\hline
\end{tabular}

\section{DISCUSSION}

Pollutants discharged into peat swamp forest affect the water quality such as acidification of downstream water bodies that increase BOD of the river water. BOD level found to be high both in river water of BISS (3.60 $\mathrm{mg} \mathrm{L}^{-1}$ ) and LSTS $\left(3.55 \mathrm{mg} \mathrm{L}^{-1}\right)$. Whereas, this BOD is one of the essential parameter that indicates the pollutant level as a consequence of discharged domestic and agricultural wastes. Moreover, high level of BOD could be because of excessive use of fertilizer in the palm oil plantation. The BOD level increases with enhanced natural plant decaying process (Hamzah, 2007; Hoai et al., 2006). Researchers have frequently used BOD and DO to evaluate the water quality on different reservoirs, bays and rivers. Rudolf et al. (2002) used DO content as an index of water quality to estimate the effect of industrial and municipal effluents on the waters of San Vicente Bay in Chile. Sanchez et al. (2006) used the Water Quality Index (WQI) and the dissolved oxygen Deficit (D) as indicators of the environmental quality of watersheds located in Las Rozas, Madrid (Spain). DO is utilized in the process of respiration and decomposition and only slightly soluble in water and it is most significant parameter for respiration of aerobic microorganism and other aerobic life forms in water (Smith, 2004). In the present study, DO level in the polluted river of peat swamp forest at BISS and LSTS found very low (3.37$3.86 \mathrm{mg} \mathrm{L}^{-1}$ ) which could be due to discharge of high organic matter content that eventually caused lack of oxygen in the water. Low level DO (0.54-1.76 $\left.\mathrm{mg} \mathrm{L}^{-1}\right)$ was also found in the Bebar River, Pehang (Gasim et al., 2007) and in the peat swamp forest of LoaganBunutMarudi Sarawak DO ranges from 0.75 to $4.33 \mathrm{mg} \mathrm{L}^{-1}$ (Lau et al., 2005). The shallow and stagnant water available in the river water also contributes to the low level of DO (Lau et al., 2005).

In aquatic systems, excessive organic and inorganic input (from industrial and urban waste) with limited mixing may reduce the availability of oxygen, in severe cases, environmental hypoxia $\left(<2.8 \mathrm{mg} \mathrm{O}_{2} \mathrm{~L}^{-1}\right)$ or anoxia $\left(0.0 \mathrm{mg} \mathrm{O}_{2} \mathrm{~L}^{-1}\right)$, where oxygen is completely unavailable for aquatic respiration (Mcneil and Closs, 2007). The effect of oxygen in such waters can sometime depends entirely on production from algae and macrophytes and severe hypoxia or anoxia may occur, most commonly overnight, if the rate of oxygen diffusion or production by photosynthesis is insufficient to meet the rate of oxygen consumption by aquatic organisms (Mcneil and Closs, 2007). According to Department of Environment Malaysia (DEM, 2009) under the National Water Quality Standards for Malaysia (INWQS), $5-7 \mathrm{mg} \mathrm{L}^{-1}$ of DO is recommended for optimum fish health, below this level harmful effects have been recorded. Low level of DO (less than $2 \mathrm{mg} \mathrm{L}^{-1}$ ) has been reported in fish mortality. Sensitivity to low level is a species specific; however, most species are distressed when it falls between 2 and $4 \mathrm{mg} \mathrm{L}^{-1}$.

Behaviour of COD was opposite to DO. In the present study minimum value of COD was recorded in SBS (8.91 $\mathrm{mg} \mathrm{L}^{-1}$ ) under LIR category whereas BISS showed higher COD level $\left(38 \mathrm{mg} \mathrm{L}^{-1}\right)$ under IR. The COD level in IR exceeded the recommended limit of 10$15 \mathrm{mg} \mathrm{L} \mathrm{L}^{-1}$ of NWQS. The agricultural and oil palm plantation activities may have caused pollution through higher COD in the river water of BISS and LSTS. Excessive logging activities, forest clearing and conversion for other land uses such as oil palm plantation might have reinforced the pollution in those sites. On the contrary, water quality of PSBS and SBS representing LIR is influenced by the natural peat swamp forest. Khan et al. (2003) observed similar trend in COD values in Huderia drain, Pakistan which was polluted from industrial and municipal waste.

Suspended solids consist of inorganic particles (clay, silt) and organic materials (algae, bacteria, phytoplankton, plantfiber) in water (Abdullah, 2008; Makhlough, 2008). Other sources of suspended solids 
are natural and human activities such as soil erosion from agriculture, urban run-off or forestry (US EPA, 2005). Sunlight penetrating through high suspended solids in the water hinders aquatic life forms and growth of phytoplankton (Makhlough, 2008). The present study shows lower TSS level (less than $30 \mathrm{mg} \mathrm{L}^{-1}$ ) in PSBS and SBS than BISS and LSTS. However, TSS level ranging from $25-50 \mathrm{mg} \mathrm{L}^{-1}$ is still acceptable for the river water in Malaysia (Gasim et al., 2006). This indicates that there was no significant pollution through erosion occurred any of the six study sites.

Conversion of peat swamp forest to other land uses generates both positive and negative impacts in Malaysia. Development of peat swamp forests provides employment and business opportunities to local communities, reducing rural-urban migration, providing market access for local products and provision of amenities and infrastructure as well as generation of revenues for the state. On the other hand conversion of peat swamp forests to other land uses will affect both human health and environmental quality and the extent of these impacts varies, ranging from local to regional and global. They include the loss of biodiversity, water and air pollution, flooding and micro-climate changes. Some of these impacts are reversible, while others are semipermanent or sometimes irreversible. For converting mangrove forests into other land uses such as for planting rice, coconut and palm oil, Sarawak has already lost 4,000 ha of mangrove reserve (Chan, 1987). The conversion of peat swamp forest to other land uses affect the peat and impair its functions is also reported by (Peter, 2003). But the present study showed that water quality has deteriorated due to such agricultural activities. Sawal and Mamit (1998) has reported that major agricultural and non-point source pollution occurred due to activities such as agrochemical application, irrigation, planting and harvesting that discharge various types pollutants such as sediments, nutrients, pathogens, pesticides and salts.

\section{CONCLUSION}

Surface waters quality depends not only on natural processes but also on anthropogenic influences. The assessment of the quality and understanding the possible influences is mostly based on vast amounts of physical, chemical and biological data, which if processed using descriptive univariate methods is of little value to decision makers. Multivariate statistical methods have been proven as suitable for assessment of data sets having multidimensional complex characteristics.
In this study, different multivariate statistical methods were used to assess temporal and spatial variations in water quality of watercourses of Sarawak, Malaysia. Hierarchical CA analysis grouped one year data into three periods (dry, intermediate and wet) and classified 6 sampling sites (peat swamp forest and oil palm plantation sites converted from peat swamp forest) into three groups (IR, LIR and RUR) based on the similarity of water quality characteristics. The temporal and spatial similarities and groupings could facilitate the design of an optimal future monitoring strategy that could decrease monitoring frequency, the number of sampling stations and the corresponding costs for the Sarawak province. Moreover, DFA provided better results both temporally and spatially with great discriminatory ability, according to significance tests. DFA rendered an important reduction in the required amount of data for the six groups of monitoring sites, because it only used three parameters $\left(\mathrm{pH}, \mathrm{NH}_{3}-\mathrm{N}\right.$ and BOD) for spatial analysis and three parameters (EC, TUR and COD) for temporal analysis. Therefore, DFA allowed a reduction in the dimensionality of the large data set and indicated a few significant parameters responsible for large variations in water quality that could reduce the number of sampling parameters. Hence, this study indicates that multivariate statistical tools and methods are an excellent exploratory tool for interpreting complex water quality data sets and for understanding temporal and spatial variations, which are useful and effective or water quality management.

This study also revealed that due to conversion of peat swamp forest into palm oil plantation water quality had deteriorated significantly as was evident from spatial variation of water quality parameters. Therefore, the mangrove forests of Sarawak should be conserved and protected from other land uses and point source of pollution.

With the rapid development taking place in Malaysia, where vast peat swamp forest areas have been identified as potential development areas, there is an urgent need to formulate a holistic, integrated and comprehensive multisectoral plan for peat swamp forest management and conservation. In particular, greater attention should now be focused on conserving some of what is left, for, inter alia, biodiversity, water resources, recreation, climate regulation and hydrological regimes. This will ensure that peat swamp forest is utilized wisely to generate economic benefits for the state and at the same time to ease resource use conflicts. We need to explore strategies and applications of new technologies to minimise the adverse impacts of peat and oil palm 
plantation development on the surrounding environment and maintain water quality. Further more, through implementing decentralized coastal zone management that requires a shift in management regimes from conventional management, with its maximizing and balancing the exploitation of peat swamp and palm oil resources, into a more participative decision-making and interactive development process to sustain the coastal zones of Malaysia. Raising awareness in the field of watershed and environmental managements and education programmes to promote better understanding of peat and oil palm plantation management and their ecosystems could be one of the national initiatives of Malaysian Government. Strategic research and development to explore various options to sustainably manage peat and oil palm in Sarawak should be initiated. Follow-up input is needed so that strategies and action plans to address issues related to the conservation and management of the watershed areas can be developed. This should be done irrespective of the status and condition of peat swamp forests, so that these resources will continue to play a vital role in socioeconomic development, environmental quality protection and ensuring that future generations will be able to enjoy the benefits derived from these oil palm and peat swamp forests as much as at present.

Due to lack of fund, the present study failed to investigate spatial and temporal variations in same river water running through different peat swamp and oil palm plantation sites. Thus, without setting two separate experiments for investigating the spatial and temporal variations of water quality a single experiment would bring about precise information. Further research on continuous monitoring of same river water quality in different seasons in different sites to estimate the spatial and temporal variations could be suggested. However, the present study would give better understanding involved in forestry and environmental development and research to expedite ways and means for the peat swamp for conservation and maintaining water quality for the sustainable management of ecosystem resource and human life as a whole.

\section{ACKNOWLEDGEMENT}

This author is supported by the Ministry of Higher Education Malaysia. The authors sincerely thanks to the Forest Department of Sarawak, Department of Environment (DOE) and Department of Irrigation and Drainage for their kind cooperation and assistance for conducting this research. Thanks should also go to the
Department of Forestry, Universiti Putra Malaysia Bintulu Sarawak Campus for their help and assistance.

\section{REFERENCES}

Abdullah, M., 2008. Water quality studies of semenyih dam. MSc. Thesis, Universiti Technologi Malaysia.

Adams, S., R. Titus, K. Pietesen, G. Tredoux and C. Harris, 2001. Hydro chemical characteristic of aquifers near Southerland in the Western Karoo, South Africa. J. Hydrol., 241: 91-103. DOI: 10.1016/S0022-1694(00)00370-X

Angeler, D.G., S. Sánchez-Carrillo, M.A. Rodrigo, M. Alvarez-Cobelas and C. Rojo, 2007. Does seston size structure reflect fish-mediated effects on water quality in a degraded semiarid wetland. Environ. Monitor. Assessment, 125: 9-17. DOI: 10.1007/s10661-006-9234-5

APHA, 2005. Standard Methods of Water and Wastewater. 21st Edn., American Public Health Association, Washington, DC., pp: 2-61. ISBN-10: 0875530478

Astel, A., M. Biziuk, A. Przyjazny and J. Namiesnik, 2006. Chemometrics in monitoring spatial and temporal variationsin drinking water quality. Water Res., 8: 1706-1716. DOI: 10.1016/j.watres.2006.02.018

Carpenter, S.R., N.F. Caraco, D.L. Correll, R.W. Howarth and V.H. Smith et al., 1998. Nonpointpollution of surface waters with phosphorus and nitrogen. Ecological Applic., 83: 559-568. DOI: 10.1890/1051-0761(1998)008

Chan, H.T., 1987. Status Report: Malaysia. In: Mangroves of Asia and the Pacific: Status and Management: Technical Report of the UNDP/UNESCO Research and Training Pilot Programme on Mangrove Ecosystems in Asia and the Pacific (RAS/79/002), Umali, R.M. (Ed.), Philippines.

DEM, 2009. National Water Quality Standards for Malaysia. Department of Environment Malaysia

Gasim, M.B., M.E. Toriman, S.A. Rahim, M.S. Islam and H. Juahir et al., 2006. Hydrology, water quality and land-use assessment of Tasik Chini's feeder rivers, Pahang, Malaysia. Malaysian J. Society Space, 2: 72-86.

Gasim, M.B., B.S. Ismail, M.E. Toriman and C.C. Tan, 2007. A Physicochemical assessment of the bebar river, pahang, Malaysia. Global J. Environ. Res., 1: 7-11.

Hamzah, N., 2007. Assessment on water quality and biodiversity within Sungai BatuPahat. MSc., thesis, University Technology Malaysia. 
Helena, B., R. Pardo, M. Vega, E. Barrado and L. Fernandez et al., 2000. Temporal evolution of ground water composition in an alluvial aquifer (Pisuergariver, Spain) by principal component analysis. Water Res., 34: 807-816. DOI: 10.1016/S0043-1354(99)00225-0

Hill, T. and P. Lewicki, 2006. Statistics: Methods and Applications. 1st Edn., StatSoft, Inc., ISBN-10: 1884233597, pp: 800.

Hoai, T.L., D. Guiral and C. Rougier, 2006. Seasonal change of community structure and size spectra of zooplankton in the kaw river estuary (French Guiana). Estuarine Coastal Shelf Sci., 68: 47-61.

Johnson, R.A. and D.W. Wichern, 1992. Applied multivariate statistical analysis. 5th Edn., New Jersey, Prentice-Hall, ISBN-10: 0131877151.

Kent, M. and P. Coker, 1992. Vegetation description and analysis: A practical approach. 1st Edn., CRC Press, Boca Raton, The University of Michigan, ISBN-10: 0849377560, pp: 363.

Khan, M.H., N. Khan and H. Aslam, 2003. Hudiara drain-A case of trans-boundary water pollution between India and Pakistan. Pak. J. Biol. Sci., 6: 167-175. DOI: 10.3923/pjbs.2003.167.175

Kowalkowski, T., R. Zbytniewski, J. Szpejna and B. Buszewski, 2006. Application chemo metrics in river water classification. Water Res., 40: 744-752. DOI:10.1016/j.watres.2005.11.042

Lambrakis, N., A. Antonakos and G. Panagopoulos, 2004. The use of multi component statistical analysis in hydro geological environmental research. Water Res., 38: 1862-1872. DOI: 10.1016/j.watres.2004.01.009

Lattin, J.M., J.D. Carroll and P.E. Green, 2003. Analyzing multivariate data. 1st Edn., Illustrated, Pacific Grove, Brooks/Cole-Thomson Learning, ISBN-10: 0534349749, pp: 556.

Lau, S., M. Murtedza, A. Kasing, A. Bong and A. Sayok et al., 2005. Water quality of loaganbunut, marudi, sarawak. Scientific Journey Through Borneo: LoaganBunut-the Wetland Heritage of Sarawak.

Liu, C.W., K.H. Lin and Y.M. Kuo, 2003. Application offactor analysis in the assessment of groundwater quality in a black foot disease area in Taiwan. Sci. Total Environ., 313: 77-89. DOI: 10.1016/S00489697(02)00683-6

Makhlough, A., 2008. Water quality characteristics of mengkuang reservoir based on phytoplankton community structure and physic-chemical analysis. MSc. thesis, University Sciences Malaysia.
McKenna, J., 2003. An enhanced cluster analysis program with bootstrap significance testing for ecological community analysis. Environ. Mod. Software, 18: 205-220. DOI: 10.1016/S13648152(02)00094-4

Mcneil, D.G. and G.P. Closs, 2007. Behavioural responses of a south-east Australian floodplain fish community to gradual hypoxia. Freshwater Biol., 52: 412-420. DOI: $10.1111 /$ j.1365-2427.2006.01705.x

Melina, E.K., A.G. Vlessidis, N.C. Thanasoulias and N.P. Evmiridis, 2005. Assessment of river water quality in northwestern Greece. Water Resources Manage., 19: 77-94. DOI: 10.1007/s11269-005-0294-z

Mokaya, S.K., J.M. Mathooko and M. Leichtfried, 2004. Influence of anthropogenic activities on water quality of atropical stream ecosystem. African J. Ecol., 42: 281-288. DOI: 10.1111/j.1365-2028.2004.00521.x

Otto, M., 1998. Multivariate Methods. In: Analytical Chemistry. Weinheim: Wiley-VCH.916p. Kellner, R., J.M. Mermet, M. Otto and H.M. Widmer (Eds.), ISBN 3-527-28610-1.

Papatheodorou, G., G. Demopoulou and N. Lambrakis, 2006. A long-term study of temporal hydrochemical data in as hallow lake using multivariate statistical techniques. Ecological Mod., 193: 759-776. DOI: 10.1016/j.ecolmodel.2005.09.004

Peter, S., 2003. Threats to peat swamp forest of sarawak. joint working group Malaysia-the Netherlands sustainable management of peat swamp forest of sarawak with special reference to ramin. Alterra, Wageningen UR, The Netherlands. Forest Department Sarawak, Malaysia, Sarawak Forestry Corporation, Malaysia.

Reghunath, R., T.R.S. Murthy and B.R. Raghavan, 2002. The utility of multivariate statistical techniques in hydro geochemical studies: An example from Karnataka, India. Water Res., 36: 2437-2442. DOI: 10.1016/S0043-1354(01)00490-0

Rudolf, A., R. Ahumada and C. Pe'rez, 2002. Dissolved oxygen content as an index of water quality in San Vicente Bay, Chile (36 degrees, 450S). Environ. Monitor. Assessment, 78: 89-100. DOI: 10.1023/A:1016140819487

Sanchez Lopez, F.J., M.D. Gil García, J.L. Martinez Vidal, P. A. Aguilera and A. Garrido Frenich et al., 2004. Assessment of metal contamination in DoñanaNationalpark (Spain) using Crayfish (PROCAMBURUS CLARKII). Environ. Monitor. Assessment, 93: 17-29. DOI: 10.1023/B:EMAS.0000016789.13603.e5 
Sanchez, E., M.F. Colmenarejo, J. Vicente, A. Rubio and L. Travieso et al., 2006. Use of the water quality index and dissolved oxygen deficit as simple indicators of watersheds pollution. Ecol. Indicators., 7: 315-328. DOI: 10.1016/j.ecolind.2006.02.005

Sánchez-Carrillo, S., L.C. Alatorre, R. Sánchez-Andrés and J. Garatuza-Payán, 2007. Eutrophication and sedimentation patterns in complete exploitation of water resources scenarios: An example from northwestern semi-arid Mexico. Environ. Monitor. Assessment, 132: 377-393. DOI: 10.2007/s10661006-9541-x.

Sawal, P. and J.D. Mamit, 1998. Environmental degradation of the coastal zone of Sarawak. Seminar on Land Use and Coastal Zone Management, 11-12 August, Miri, Sarawak.

Shin, P.K.S. and K.Y.S. Fong, 1999. Multiple discriminant analysis of marine sediment data. Marine Pollut. Bull., 39: 285-294. DOI: 10.1016/S0025-326X(99)00113-7

Shrestha, S. and F. Kazama, 2007. Assessment of surface water quality using multivariate statistical techniques: A case study of the Fuji river basin, Japan. Environ. Model. Software, 22: 464-475. DOI: 10.1016/j.envsoft.2006.02.001

Simeonov, V., D.L. Massart, G. Andreev and S. Tsakovski, 2000. Assessment of metal pollution based on multivariate statistical modeling of 'hot spot' sediments from the Black Sea. Chemosphere, 41: $1411-1417$. DOI: $10.1016 /$ S00456535(99)00540-8

Simeonov, V., J.W. Einax, I. Stanimirova and J. Kraft, 2002. Environmetric modeling and interpretation of river water monitoring data. Analytical Bioanalytical Chem., 374: 305-898. DOI: 10.1007/s00216-002-1559-5

Simeonov, V., J.A. Stratis, C. Samara, G. Zachariadis and A. Anthemidis et al., 2003. Assessment of the surface water quality in Northern Greece. Water Res., 37: 4119-4124. DOI: 10.1016/S00431354(03)00398-1

Simeonova, P., V. Simeonov and G. Andreev, 2003. Water quality study of the Struma River Basin, Bulgaria (1989-1998). Central Eur. J. Chem., 1: 136-212. DOI: 10.2478/BF02479264

Singh, K.P., A. Malik, D. Mohan and S. Sinha, 2004. Multivariate statistical techniques for the evaluation of spatial and temporal variations in water quality of Gomti River (India)-A case study. Water Res., 38: 3980-3992. DOI: 10.1016/j.watres.2004.06.011
Singh, K.P., A. Malik and S. Sinha, 2005. Water quality assessment and apportionment of pollution sources of Gomtiriver (India) using multivariate statistical techniques-A case study. Analytica Chim. Acta, 538: 355-374. DOI: 10.1016/j.aca.2005.02.006

SMD, 2014. Monthly rainfall review. Sarawak Meteorological Department.

Smith, J.M., 2004. Water quality trends in the black water river watershed Canaan Valley, West Virginia. MSc., Thesis., West Virginia University.

Suk, H. and K. Lee, 1999. Characterization of a ground water hydrochemical system through multivariate analysis: Clustering into ground water zones. Ground Water, 37: 358-366.

Vaidya, O.C., T. P. Smith and H. Fernand, 2008. Forestry best management practices: Evaluation of alternate streamside management zones on stream water quality in Pockwocklake and five mile lake water shades in central Nova Scotia, Canada. Environ. Monitor. Assessment, 137: 1-14. DOI: 10.1007/s10661-006-9370-y

Vega, M., R. Pardo, E. Barrado and L. Deban, 1998. Assessment of seasonal and polluting effects on the quality of river water by exploratory data analysis. Water Res., 32: 3581-3592. DOI:10.1016/S00431354(98)00138-9

Voutsa, D., E. Manoli, C. Samara, M. Sofoniou and I. Stratis, 2001. A study of surface water quality in Macedonia, Greece: Speciation of nitrogen and phosphorus. Water, Air Soil Pollut., 129: 13-32. DOI:10.1023/A:1010315608905

Wunderlin, D.A., M.D.P. Diaz, M.V. Ame, S.F. Pesce, A.C. Hued et al., 2001. Pattern recognition techniques for the evaluation of spatial and temporal variations in water quality. A case study: Suquia River Basin (Cordoba Argentina). Water Res., 35: 2881-2894. DOI: 10.1016/S0043-1354(00)00592-3

Yayýntas, O.T., Z. Yýlmaz, M. Turkoglu and Y. Dilgin, 2007. Determination of heavy metal pollution with environmental physicochemical parameters in waste water of Kocabasstream (Biga, Canakkale, Turkey) by ICP-AES. Environ. Monitor. Assessment, 27: 389-397. DOI: 10.1007/s10661-006-9288-4

Yeung, I.M.H., 1999. Multivariate analysis of the Hong Kong Victoria harbour water quality data. Environ. Monitor. Assessment, 593: 331-342. DOI: 10.1023/A:1006177824327

Yung, Y.K., C.K. Wong, K. Yau and P.Y. Qian, 2001. Long term changes in water quality and phytoplankton characteristics in Port Shelter, Hong Kong, from 1988-1998. Marine Pollut. Bull., 40: 981-992. DOI: 10.1016/S0025-326X(01)00066-2 